\title{
Cyclic swell-shrink behaviour of an expansive soil treated with a sulfonated oil
}

1 Amin Soltani PhD

Research Fellow, Department of Infrastructure Engineering, Melbourne School of Engineering, The University of Melbourne, Parkville, VIC, Australia (corresponding author: amin.soltani@unimelb.edu.au) (Orcid:0000-0002-0483-7487)

\section{Ramin Raeesi MSc}

PhD candidate, Department of Infrastructure Engineering, Melbourne School of Engineering, The University of Melbourne, Parkville, VIC, Australia (Orcid:0000-0001-7903-2205)
3 Brendan C. O’Kelly PhD, FTCD, CEng, CEnv, MICE Associate Professor, Department of Civil, Structural and Environmental Engineering, Trinity College Dublin, Dublin, Ireland (Orcid:0000-0002-1343-4428)
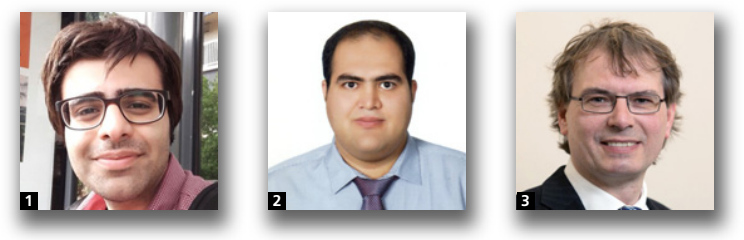

The effects of a sulfonated oil (SO) stabiliser on the swell-shrink properties of an expansive soil were investigated through cyclic wetting-drying tests. The cyclic wetting-drying action led to the reconstruction of the soil microstructure by inducing clay particle aggregation. Accordingly, the greater the number of applied cycles, the lower the swell-shrink potential up to the fourth cycle, beyond which the swelling and shrinkage strains attained elastic equilibrium. At any given cycle, the tendency for swell-shrink reduction was in favour of the so concentration up to $\mathbf{0 . 7 5} \%$, beyond which the excess so molecules self-associated in the form of aggregates, thereby acting as a 'Iubricant' rather than a clay-stabilising agent. As a result of SO treatment, the accumulated axial strain progressively transitioned towards a desirable, 'neutral' state, with $\mathbf{0 . 7 5 \%}$ sO exhibiting the highest resistance against cyclic wetting-drying. For any given SO concentration, the equalised void ratio-moisture content curves for wetting and drying followed the same S-shaped path, further corroborating that the swelling and shrinkage processes, on achieving elastic equilibrium, become reversible. The shrinkage and liquid limits indicated a progressive transition towards a desirable, aggregated fabric, with $\mathbf{0 . 7 5} \%$ SO identified as the optimum concentration.

\section{Notation}

$e_{\mathrm{H}}$

maximum void ratio with respect to the equalised void ratio-swell-shrink curve

$e_{\mathrm{L}} \quad$ minimum void ratio with respect to the equalised void ratio-swell-shrink curve

$e_{\mathrm{o}} \quad$ moulding void ratio

$e(w) \quad$ void ratio as a function of moisture content $w$

$f_{w}^{\prime}(w) \quad$ first derivative of the equalised void ratioswell-shrink curve

$m \quad$ rate of increase/decrease in $\varepsilon_{\text {ac }}$ with respect to an increase in $N(\%)$

$N \quad$ number of wetting-drying cycle(s)

$R^{2} \quad$ coefficient of determination

$S_{\mathrm{c}} \quad$ So concentration (\%)

$S_{\mathrm{R}} \quad$ degree of saturation (\%)

$\mathrm{SH}_{\mathrm{P}}(N)$ axial shrinkage potential with respect to the $N$ th drying cycle $(\%)$

$\mathrm{SW}_{\mathrm{P}}(N)$ axial swelling potential with respect to the $N$ th wetting cycle $(\%)$

$w_{\mathrm{L}} \quad$ minimum moisture content with respect to the equalised void ratio-swell-shrink curve (\%)

$w_{\mathrm{o}}$ moulding moisture content $(\%)$

$\begin{array}{ll}\alpha & \begin{array}{l}\text { fitting parameter of the equalised void } \\ \text { ratio-swell-shrink curve }\left(\%{ }^{-1}\right) \\ \text { moisture content at the inflection point of the } \\ \alpha^{-1}\end{array} \\ \beta & \begin{array}{l}\text { equalised void ratio-swell-shrink curve }(\%) \\ \text { fitting parameter of the equalised void } \\ \text { ratio-swell-shrink curve } \\ \text { moulding dry unit weight }\left(\mathrm{kN} / \mathrm{m}^{3}\right)\end{array} \\ \gamma_{\mathrm{do}} & \begin{array}{l}\text { accumulated axial strain with respect to the } N \text { th } \\ \varepsilon_{\mathrm{ac}}(N)\end{array}\end{array}$

\section{Introduction}

In arid and semi-arid climates, the design and construction of infrastructure are often adversely affected by the presence of expansive/reactive soil deposits. A notable fraction of expansive soils consists of active smectite group minerals (e.g. montmorillonite), which are highly susceptible to seasonal fluctuations and undergo significant expansion or contraction on the addition or removal of water (Soltani et al., 2019a). The consequent cyclic increase and decrease in soil volume, commonly referred to as cyclic wetting-drying, leads to foundation distortion and wall cracking and, in the case of road 
infrastructure, causes undulating and cracking of pavements and embankment slumping, which are costly to maintain and repair and also compromise road safety (Jones and Jefferson, 2012; Nelson and Miller, 1992). Accordingly, these adversities demand engineering solutions to mitigate the associated socioeconomic impacts.

The problems associated with expansive soils are often alleviated by means of various soil stabilisation techniques, which refer to a group of mechanical, chemical or combined mechanical-chemical practices capable of amending the soil fabric into a coherent matrix with improved shear strength and reduced swell-shrink volume change potential (Soltani et al., 2017; Winterkorn and Pamukcu, 1991). In this regard, the use of cementitious/calcium-based binders, such as cement and lime, still remains the most well-established and timetested soil stabilisation scheme practised over past decades (e.g. Al-Rawas et al., 2005; Estabragh et al., 2013, 2014; Garzón et al., 2015, 2016; Jha and Sivapullaiah, 2016; Nalbantoglu and Tuncer, 2001; Phanikumar and Nagaraju, 2018; Rao et al., 2008; Sharma and Sivapullaiah, 2016; Soltani et al., 2017; Thyagaraj and Zodinsanga, 2014). However, these traditional chemical stabilisers are often not financially competitive in terms of materials procurement, labour and equipment usage. Moreover, cementitious agents are often associated with major environmental drawbacks, such as the need for quarry-based materials, which have significant energy and carbon dioxide emissions footprints (Soltani et al., 2019b; Williamson and Cortes, 2014). Consequently, many developed and developing countries have initiated the transition to 'sustainable infrastructure', a concept that fosters the replacement of traditional cementitious binders with low-cost and potentially sustainable alternatives, for example, polymers, resins and sulfonated oils (SOs), thereby conserving natural resources as well as mitigating the burden on the environment by reducing the associated levels of greenhouse gas emissions.

Non-traditional chemical stabilisers such as SOs have been reported to encourage 'flocculation' or 'aggregation' in the soil matrix through direct interactions with clay particles (e.g. Akbulut et al., 2012; Park et al., 2006; Petry and Das, 2001; Scholen, 1992; Soltani et al., 2019c; Tingle et al., 2007). SOs are a group of 'amphiphilic', 'miscible' synthetic surfactants formed by treating fatty oils/acids - a carboxylic acid with a long aliphatic chain - with concentrated sulfuric acid $\left(\mathrm{H}_{2} \mathrm{SO}_{4}\right)$ or oleum $\left(\mathrm{H}_{2} \mathrm{SO}_{4} \cdot \eta \mathrm{SO}_{3}\right.$ where $\eta=$ molar free sulfurtrioxide content) through a process referred to as sulfonation (March, 1992; Scholen, 1995). A typical SO molecule, commonly expressed as $R-\left(\mathrm{SO}_{2}\right) \mathrm{OH}^{-}$(where $R=$ hydrocarbon chain), consists of two main components: $(a)$ the negatively charged 'hydrophilic' (or polar) head, represented by $\left(\mathrm{SO}_{2}\right) \mathrm{OH}^{-}$and $(b)$ the 'hydrophobic' (or non-polar) tail, represented by the hydrocarbon chain $R$ (Jones et al., 2016; Scholen, 1995). The negatively charged hydrophilic heads are attracted to the negatively charged clay particles through 'exchangeable cations' present in the vicinity of the clay surfaces; consequently, the exchangeable cations become immobilised and hence non-exchangeable, thereby reducing the soil's cation-exchange capacity (gTKP, 2006; He et al., 2018; Katz et al., 2001; Liu et al., 2009; Soltani et al., 2019c; Xiang et al., 2010). Accordingly, SO products are often marketed as ionic soil stabilisers. The second component, the hydrophobic tail, possesses 'lubricant' properties, which reduce the surface tension of water and hence facilitate the relative movement and sliding of soil particles with much less effort/friction, inducing 'contact lubrication' in the soil matrix and thereby serving as a so-called 'compaction aid', allowing a closer packing arrangement of the soil particles to be achieved during compaction (Berney et al., 2003; Greening and Page-Green, 2003; Mousavi et al., 2014; Mousavi and Karamvand, 2017; Onyejekwe and Ghataora, 2015; Soltani et al., 2019c). Quite clearly, SOs appear to have a variety of promising clay-amendment properties and, as such, could be a sustainable alternative to traditional cementitious binders. However, a review of the research literature indicates that the reported results, particularly in the context of expansive soils, are still limited and, more importantly, are not consistent towards defining an ad hoc soil stabilisation scheme; in this regard, a more detailed discussion is given by Onyejekwe and Ghataora (2015).

In view of the limited and inconsistent literature on employing SOs in ground improvement practice, the work reported in this paper examined the performance of a commercial SO stabiliser as a sustainable solution towards mitigating the swell-shrink volume change potential of an expansive soil. The experimental programme consisted of soil consistency and cyclic wetting-drying tests, carried out at four different SO concentrations, in addition to untreated soil (control). The basic principles of chemistry, in conjunction with the soil mechanics framework, were employed to identify the clay SO-amending mechanisms, and to predict and hence perceive the evolution of the soil fabric in response to alternate wetting and drying.

\section{Materials}

\subsection{Expansive soil}

The soil used in this study consisted of $45 \%$ clay $(<2 \mu \mathrm{m})$, $42 \%$ silt $(2-75 \mu \mathrm{m})$ and $13 \%$ sand $(0 \cdot 075-4.75 \mathrm{~mm})$; its pertinent physical and mechanical properties, as determined in accordance with relevant American Society for Testing and Materials (ASTM) standards, are summarised in Table 1. Throughout this study, the moisture content was determined using the oven-drying method with a drying temperature of $110^{\circ} \mathrm{C}$ in accordance with ASTM D 2216 (ASTM, 2019). The liquid limit (LL) and plastic limit (PL) of the soil were measured as $\mathrm{LL}=80 \cdot 2 \%$ and $\mathrm{PL}=24 \cdot 1 \%$, thus producing a plasticity index (PI) of $56 \cdot 1 \%$, such that the soil was classified as clay with high plasticity $(\mathrm{CH})$ in accordance with the unified soil classification system (USCS). The free swell index (FSI) was determined to be $133 \%$; following the classification criterion 
Table 1. Physical and mechanical properties of the expansive soil investigated

\begin{tabular}{|c|c|c|}
\hline Property & Value/description & Standard \\
\hline Specific gravity of solids, $G_{s}$ & $2 \cdot 76$ & ASTM D 854 (ASTM, 2014a) \\
\hline Sand fraction $(0.075-4.75 \mathrm{~mm}): \%$ & 13 & ASTM D 422 (ASTM, 2007) \\
\hline Silt fraction $(2-75 \mu \mathrm{m}): \%$ & 42 & ASTM D 422 (ASTM, 2007) \\
\hline Clay fraction $(<2 \mu \mathrm{m}): \%$ & 45 & ASTM D 422 (ASTM, 2007) \\
\hline LL: $\%^{a}$ & $80 \cdot 2$ & ASTM D 4318 (ASTM, 2017a) \\
\hline $\mathrm{PL}: \%^{\mathrm{b}}$ & $24 \cdot 1$ & ASTM D 4318 (ASTM, 2017a) \\
\hline $\mathrm{PI}=\mathrm{LL}-\mathrm{PL}: \%$ & $56 \cdot 1$ & ASTM D 4318 (ASTM, 2017a) \\
\hline USCS classification & $\mathrm{CH}$ & ASTM D 2487 (ASTM, 2017b) \\
\hline FSI: \% ${ }^{c}$ & 133 & IS 1948 (BIS, 1970) \\
\hline Degree of expansivity & High & IS 1948 (BIS, 1970) \\
\hline Optimum moisture content, $w_{\text {opt }}: \%$ & $18 \cdot 6$ & ASTM D 698 (ASTM, 2012) \\
\hline Maximum dry unit weight, $\gamma_{\text {dmax }}: \mathrm{kN} / \mathrm{m}^{3}$ & $16 \cdot 7$ & ASTM D 698 (ASTM, 2012) \\
\hline Minimum void ratio for compaction, $e_{\min }{ }^{d}$ & 0.624 & ASTM D 698 (ASTM, 2012) \\
\hline
\end{tabular}

apercussion-cup method

${ }^{\mathrm{b}}$ Thread-rolling method

${ }^{c} \mathrm{FSI}=\left(V_{\mathrm{D}}-V_{\mathrm{K}}\right) / V_{\mathrm{K}} \times 100$ (where $V_{\mathrm{D}}$ and $V_{\mathrm{K}}$ are the equilibrium sediment volumes of $10 \mathrm{~g}$ oven-dried soil, passing a $425 \mu \mathrm{m}$ sieve, when placed in distilled water and kerosene, respectively)

${ }^{\mathrm{d} C o m p u t e d ~ f r o m ~} e_{\min }=G_{s} \gamma_{w} / \gamma_{\mathrm{dmax}}-1$ (where $\gamma_{\mathrm{w}}=$ unit weight of water)

suggested in IS 1948 (BIS, 1970), the soil was categorised as 'highly expansive'. Other mechanical attributes included a relatively high optimum moisture content (for standard Proctor compaction) of $w_{\mathrm{opt}}=18 \cdot 6 \%$, along with a maximum dry unit weight of $\gamma_{\mathrm{dmax}}=16.7 \mathrm{kN} / \mathrm{m}^{3}$; the latter produced a minimum void ratio for compaction of $e_{\min }=0.624$.

\subsection{SO}

A commercially available SO product was used as the soilstabilising agent. It was supplied in liquid concentrate form and was diluted with water for application. The physical and chemical properties of the used SO product, as supplied by the manufacturer, are summarised in Table 2. Its main attributes included an acidic $\mathrm{pH}$ of $3 \cdot 1$, a specific gravity of 1.05 and a rather low molecular weight of $3 \cdot 8 \times 10^{-4} \mathrm{Mg} / \mathrm{mol}$. As specified in the manufacturer's literature, the product contains two main application prerequisites: $(a)$ clay content $>15 \%$ and (b) PI $>11 \%$. As evident from Table 1 , the expansive soil used in this study - clay content $=45 \%$ and PI $=56 \cdot 1 \%$ - clearly met these criteria.

\section{Experimental programme}

\subsection{Mix design and sample preparation}

As outlined in Table 3, five mix designs, consisting of one control (hereafter referred to as the natural soil) and four SOtreated blends, were investigated. For ease of presentation, a simple coding system - defined as $\mathrm{SO}_{x}$ where $x$ is the SO concentration (in \%) - was adopted to designate the various mix designs. Moreover, the SO concentration and target/moulding moisture content with respect to the five mix designs were, respectively, defined as

1. $S_{\mathrm{c}}(\%)=\frac{M_{\mathrm{SO}}}{M_{\mathrm{W}}} \times 100$
Table 2. Physical and chemical properties of the used SO agent

\begin{tabular}{ll} 
Property & Value/description \\
\hline Physical state & Viscous liquid \\
Appearance & Reddish-brown \\
Odour & Slightly pungent \\
Flammability & Non-flammable \\
Solubility in water $\left(\right.$ at $\left.25^{\circ} \mathrm{C}\right): \%$ & 100 \\
Specific gravity, $\mathrm{G}_{\mathrm{s}}\left(\right.$ at $\left.25^{\circ} \mathrm{C}\right)$ & $1 \cdot 05$ \\
Molecular weight, $\mathrm{M}: \mathrm{Mg} / \mathrm{mol}$ & $3 \cdot 8 \times 10^{-4}$ \\
Vapour pressure: $\mathrm{mm} \mathrm{mercury}$ & 20 \\
Freezing point: ${ }^{\circ} \mathrm{C}$ & -10 \\
Boiling point: ${ }^{\circ} \mathrm{C}$ & 100 \\
Acidity, pH (at $25^{\circ} \mathrm{C}$ ) & $3 \cdot 1$ \\
Chemical formulation & $R-\left(\mathrm{SO}_{2}\right) \mathrm{OH}^{-\mathrm{a}}$
\end{tabular}

${ }^{\mathrm{a}} R=$ Hydrocarbon chain

2. $w_{\mathrm{o}}(\%)=\frac{M_{\mathrm{W}} \text { or } M_{\mathrm{DSO}}}{M_{\mathrm{S}}} \times 100$

where $S_{\mathrm{c}}$ is the SO concentration, $w_{\mathrm{o}}$ is the target/moulding moisture content, $M_{\mathrm{SO}}$ is the mass of pure SO (in liquid concentrate form), $M_{\mathrm{W}}$ is the mass of water, $M_{\mathrm{DSO}}$ is the mass of diluted SO and $M_{\mathrm{S}}$ is the mass of soil solids.

The required mass of liquid - either water (for $\mathrm{SO}_{0}$ ) or diluted $\mathrm{SO}$ (for $\mathrm{SO}_{0.25}, \mathrm{SO}_{0.50}, \mathrm{SO}_{0.75}$ and $\mathrm{SO}_{1 \cdot 00}$ ) - corresponding to the targeted moisture content of $w_{\mathrm{o}}=18.6 \%$ (i.e. the identified standard Proctor optimum moisture content for the natural soil) was added to the oven-dried soil and then thoroughly mixed for approximately $10 \mathrm{~min}$. Great care was taken to pulverise any clumped particles, particularly for the higher SO concentrations, thereby targeting homogeneity of the various blends. As evident from Table 3, the LL and PL, as well as the PI $(\mathrm{PI}=\mathrm{LL}-\mathrm{PL})$, all reduced exponentially with increasing 
Table 3. Mix designs and their properties

\begin{tabular}{|c|c|c|c|c|c|c|c|c|}
\hline Mix & $S_{c}: \%^{a}$ & LL: ${ }^{b}$ & PL: ${ }^{b}$ & PI: ${ }^{b}$ & $w_{\mathrm{o}}: \%$ & $\gamma_{\mathrm{do}}: \mathrm{kN} / \mathrm{m}^{3}$ & $e_{0}^{c}$ & $n^{d}$ \\
\hline $\mathrm{SO}_{0}$ & 0 & $80 \cdot 2$ & $24 \cdot 1$ & $56 \cdot 1$ & $18 \cdot 6$ & $16 \cdot 7$ & 0.624 & 7 \\
\hline $\mathrm{SO}_{0.25}$ & 0.25 & $77 \cdot 2$ & $23 \cdot 8$ & $53 \cdot 4$ & $18 \cdot 6$ & $16 \cdot 7$ & 0.624 & 7 \\
\hline $\mathrm{SO}_{0.50}$ & 0.50 & $73 \cdot 1$ & $21 \cdot 1$ & $52 \cdot 0$ & $18 \cdot 6$ & $16 \cdot 7$ & 0.624 & 7 \\
\hline $\mathrm{SO}_{0.75}$ & 0.75 & $71 \cdot 2$ & $20 \cdot 3$ & $50 \cdot 8$ & $18 \cdot 6$ & $16 \cdot 7$ & 0.624 & 7 \\
\hline $\mathrm{SO}_{1.00}$ & 1.00 & 69.9 & $19 \cdot 2$ & $50 \cdot 7$ & $18 \cdot 6$ & $16 \cdot 7$ & 0.624 & 7 \\
\hline
\end{tabular}

${ }^{a} S O$ concentration, defined by Equation 1

${ }^{\mathrm{b}}$ ASTM D 4318 (ASTM, 2017a)

${ }^{\mathrm{C}}$ Target void ratio, computed from $e_{\mathrm{o}}=G_{\mathrm{s}} \gamma_{\mathrm{w}} / \gamma_{\mathrm{do}}-1$

${ }^{\mathrm{d}}$ Number of prepared samples

SO concentration over the investigated range, indicative of a general reduction in soil expansivity. For instance, the natural soil sample $\left(\mathrm{SO}_{0}\right)$ resulted in $\mathrm{PI}=56 \cdot 1 \%$, while samples $\mathrm{SO}_{0 \cdot 25}$, $\mathrm{SO}_{0.50}, \mathrm{SO}_{0.75}$ and $\mathrm{SO}_{1.00}$ produced lower PI values of 53.4 , $52 \cdot 0,50 \cdot 8$ and $50 \cdot 7 \%$, respectively.

Samples for the cyclic wetting-drying tests (see Section 3.2) were formed in three equal-height layers by 'static compaction' in a series of $75 \mathrm{~mm}$ diameter, $20 \mathrm{~mm}$ high oedometer moulds (or confining rings), each layer having achieved the targeted dry unit weight of $\gamma_{\mathrm{do}}=16.7 \mathrm{kN} / \mathrm{m}^{3}$ (i.e. the identified standard Proctor maximum dry unit weight for the natural soil). The compacted samples were then enclosed in multiple layers of cling wrap and maintained at ambient laboratory temperature for $24 \mathrm{~h}$ to allow a uniform distribution of moisture throughout each sample mass. Moreover, to ensure uniformity of the fabric and hence repeatability in behaviour, after the $24 \mathrm{~h}$ standing period, the dry unit weight and moisture content were measured (and compared with each other) at various locations of the compacted samples. This was achieved by slicing each of the compacted samples into four equal-radius quarters and testing each quarter for dry unit weight and moisture content. Typical results for samples $\mathrm{SO}_{0}$ and $\mathrm{SO}_{0.75}$ are provided in Figures 1(a) and 1(b), respectively. Overall, the variations of both dry unit weight and moisture content were found to be marginal, as supported by the low standard deviation (SD) and coefficient of variation $(\mathrm{CV})$ values, thus corroborating the suitability and repeatability of the implemented sample preparation technique.

\subsection{Cyclic wetting-drying test}

The natural soil and various SO-treated samples were subjected to alternate wetting and drying in a temperature-controlled oedometer set-up (see Figure 2); the apparatus employed was similar in design to those previously reported in the research literature (e.g. Estabragh et al., 2015, 2018; Soltani et al., 2019c; Tripathy et al., 2002; Tripathy and Subba Rao, 2009). Referring to Figure 2, much like a conventional oedometer setup, the temperature-controlled variant used in this study consisted of a brass cell, an axial loading mechanism (4) and a vertical-displacement dial gauge (1). Additional components
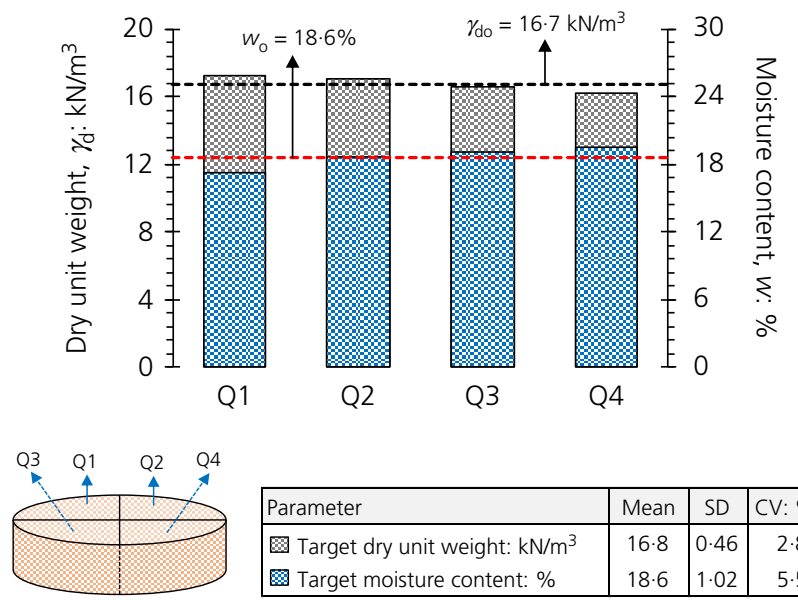

\begin{tabular}{|l|c|c|c|}
\hline Parameter & Mean & SD & CV: \% \\
\hline Oarget dry unit weight: $\mathrm{kN} / \mathrm{m}^{3}$ & 16.8 & 0.46 & 2.8 \\
圆 Target moisture content: \% & 18.6 & 1.02 & 5.5 \\
\hline
\end{tabular}

(a)
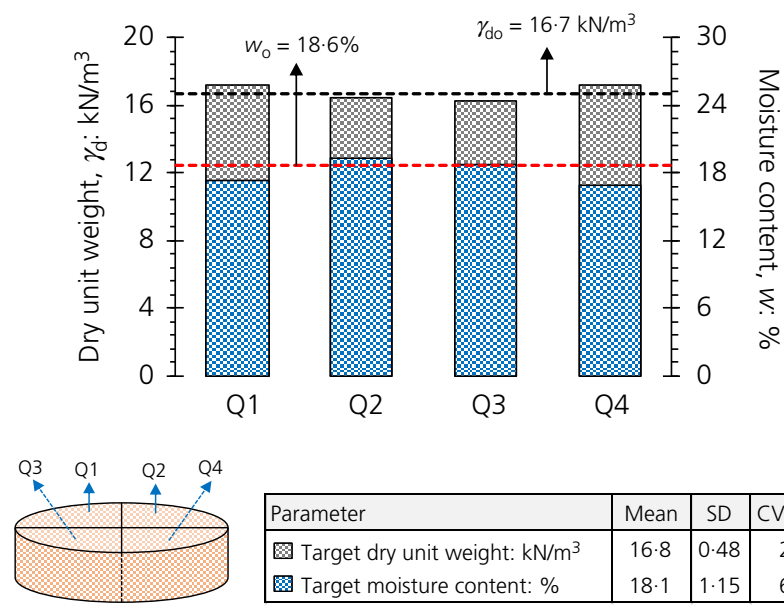

\begin{tabular}{|l|c|c|c|}
\hline Parameter & Mean & SD & CV: $\%$ \\
\hline O Target dry unit weight: $\mathrm{kN} / \mathrm{m}^{3}$ & $16 \cdot 8$ & $0 \cdot 48$ & $2 \cdot 8$ \\
⿴囗大 Target moisture content: \% & $18 \cdot 1$ & $1 \cdot 15$ & $6 \cdot 3$ \\
\hline
\end{tabular}

(b)

Figure 1. Variations of dry unit weight and moisture content for the quartered compacted samples: (a) $\mathrm{SO}_{0}$; (b) $\mathrm{SO}_{0.75}$

included a drainage valve (9), an electronic heating system $(7,8,13-15)$ and a perforated loading cap/plate $(3,5)$. The drainage valve was fitted in the base of the brass oedometer cell, and facilitated drainage of inundation water (from it) at the conclusion of the wetting tests. The heating system, 


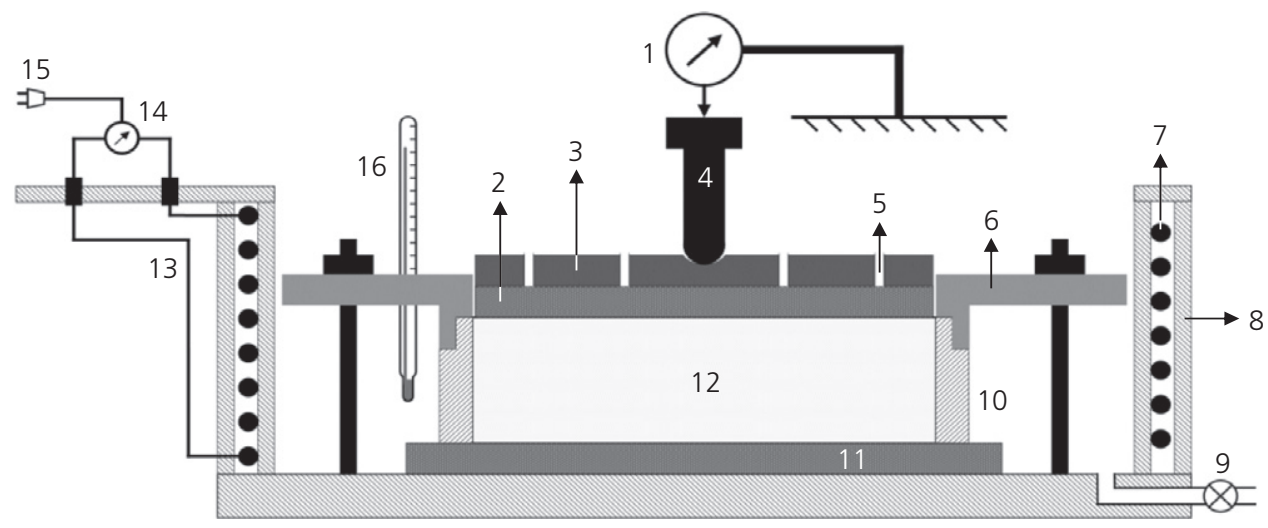

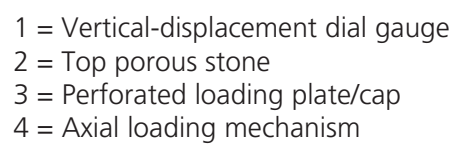

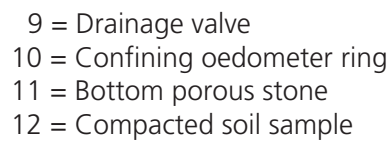

$13=$ Electrical wire

$14=$ Temperature controller

$15=$ Power supply

$16=$ Thermometer

Figure 2. Schematic layout of the temperature-controlled oedometer apparatus

which simulated the drying process, was embedded in the sidewall of the oedometer cell, and was capable of imposing and maintaining temperatures between $30^{\circ} \mathrm{C}$ and $70^{\circ} \mathrm{C}$. Prior to testing, temperature calibration was carried out by means of a commercial thermometer (16) mounted within the oedometer cell.

In performing the wetting-drying testing, the desired sample, statically compacted in the confining ring $(10,12)$ and placed within the oedometer cell between two porous stones $(2,11)$, was inundated with water and allowed to freely swell at ambient laboratory temperature under a low nominal vertical stress of $1 \mathrm{kPa}$ (ASTM D 4546 (ASTM, 2014b)). The incurred axial swelling strain response was monitored regularly by means of the displacement dial gauge until such time that the ultimate swelling strain, denoted as the 'swelling potential', could be determined. On completion of the wetting process, the reservoir/inundation water was allowed to drain from the oedometer cell by way of the drainage valve. The heating system was then switched on and drying of the sample was attempted at a constant temperature of $40 \pm 2^{\circ} \mathrm{C}$. The drying process was continued until such time that the ultimate shrinkage strain, denoted as the 'shrinkage potential', could be determined. The combination of one wetting process and the follow-on drying process is designated as one wetting-drying cycle. It is well accepted that the swelling and shrinkage potentials either increase or decrease with an increase in the number of imposed wetting-drying cycles; regardless of the exhibited trend, they both attained equilibrium after the completion of several cycles (Subba Rao, 2000). In this investigation, the equilibrium condition was mainly accomplished at the fourth cycle; therefore, only five wetting-drying cycles were performed on the various prepared samples. At any given cycle, the swelling or shrinkage potential was obtained from Equation 3
(Soltani et al., 2019a)

$$
\text { 3. } \mathrm{SW}_{\mathrm{P}}(N) \text { or } \mathrm{SH}_{\mathrm{P}}(N)=\frac{\Delta H_{\mathrm{F}}(N)}{H_{\mathrm{o}}(N-1)} ; N=\{1,2,3, \ldots\}
$$

where $\operatorname{SW}_{\mathrm{P}}(N)$ and $\mathrm{SH}_{\mathrm{P}}(N)$ are the swelling and shrinkage potentials at the $N$ th wetting and drying cycles, respectively (in $\%), \Delta H_{\mathrm{F}}(N)$ is the change in sample height at conclusion of the $N$ th wetting or drying cycle and $H_{\mathrm{o}}(N-1)$ is the sample height prior to commencement of the $N$ th wetting or drying cycle.

In addition to the swelling and shrinkage potentials, the variations in void ratio and moisture content were also measured during the concluding wetting and drying stages. For each mix design, this was achieved by means of multiple identical/ duplicate samples, as commonly practised in the research literature (e.g. Estabragh et al., 2015, 2018; Tripathy et al., 2002). For wetting, five identically prepared samples were each subjected to the same cyclic wetting-drying process described above, and dismantled at various stages during the final wetting cycle. The obtained samples were then tested for void ratio (ASTM D 427 (ASTM, 2004)) and moisture content (ASTM D 2216 (ASTM, 2019)) to arrive at the void ratio-moisture content relationship covering the duration of the concluding wetting cycle. A similar procedure, involving only one duplicate sample, was followed for the final drying cycle. In this case, on completion of the final wetting cycle, the swollen duplicate sample was carefully removed from the oedometer cell and transferred to a conventional oven where oedometer drying was replicated by imposing a constant oven temperature of $40^{\circ} \mathrm{C}$. The duplicate sample, undergoing oven drying, was regularly tested for void ratio and moisture content until such time that shrinkage ceased. In view of the above, for each mix design, a total of 
seven samples - that is, one main sample for axial strain measurements and six duplicate samples for void ratio-moisture content evaluations - were prepared and tested.

\section{Results and discussion}

\subsection{Swelling and shrinkage potentials}

Figure 3(a) illustrates the variations of swelling potential $\mathrm{SW}_{\mathrm{P}}$, obtained by Equation 3, against the number of applied wetting-drying cycles $N$ for the natural soil and various SOtreated samples. For any given SO concentration, the greater the number of applied cycles, the lower the swelling potential, following an exponentially decreasing trend up to the equilibrium cycle, or $N=4$. Beyond the fourth cycle, the reductions in swelling potential were found to be negligible, especially for the SO-treated samples. For instance, the natural soil sample $\left(\mathrm{SO}_{0}\right)$ resulted in $\mathrm{SW}_{\mathrm{P}}=26 \cdot 4,21 \cdot 2,15 \cdot 7,14 \cdot 5,13 \cdot 4$ and $13 \cdot 3 \%$ at $N=1-6$, respectively. Similarly, at any given cycle, the greater the SO concentration, the lower the swelling potential; however, compared with $0.75 \% \mathrm{SO}$, the relative reduction in swelling potential for $1 \% \mathrm{SO}$ was found to be marginal - for further reference, compare the five trend curves specified in Figure 3(a). At $N=2$, for instance, samples $\mathrm{SO}_{0}, \mathrm{SO}_{0 \cdot 25}$, $\mathrm{SO}_{0.50}, \mathrm{SO}_{0.75}$ and $\mathrm{SO}_{1 \cdot 00}$ resulted in $\mathrm{SW}_{\mathrm{P}}=21 \cdot 2,16 \cdot 6,15 \cdot 2$, 10.5 and $9 \cdot 9 \%$, respectively. Interestingly, the magnitude of swelling improvement at any given SO concentration was found to be inversely proportional to the number of applied cycles, and achieved a so-called 'stabilised state' on completion of the equilibrium cycle $(N=4)$. As a typical case, the use of $0 \cdot 75 \%$ SO promoted a $51 \%$ improvement/reduction in the swelling potential at $N=2\left(\mathrm{SW}_{\mathrm{P}}\right.$ decreased from $21 \cdot 2 \%$ for $\mathrm{SO}_{0}$ to $10.5 \%$ for $\mathrm{SO}_{0.75}$ ), while a lower improvement of $26 \%$ was

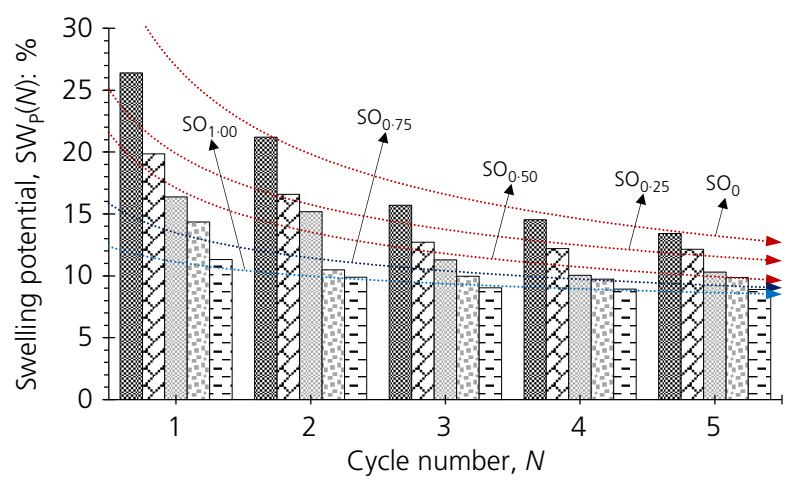

(a)

\begin{tabular}{|l|c|c|c|c|c|c|}
\hline Sample & $N=1$ & $N=2$ & $N=3$ & $N=4$ & $N=5$ & $N=6$ \\
\hline 冈 $\mathrm{SO}_{0}$ & $26 \cdot 4 \%$ & $21 \cdot 2 \%$ & $15 \cdot 7 \%$ & $14 \cdot 5 \%$ & $13 \cdot 4 \%$ & $13 \cdot 3 \%$ \\
$\square \mathrm{SO}_{0.25}$ & $19 \cdot 9 \%$ & $16 \cdot 6 \%$ & $12 \cdot 7 \%$ & $12 \cdot 2 \%$ & $12 \cdot 2 \%$ & - \\
$\square \mathrm{SO}_{0.50}$ & $16 \cdot 4 \%$ & $15 \cdot 2 \%$ & $11 \cdot 3 \%$ & $10 \cdot 0 \%$ & $10 \cdot 3 \%$ & - \\
$\square \mathrm{SO}_{0.75}$ & $14 \cdot 4 \%$ & $10 \cdot 5 \%$ & $10 \cdot 0 \%$ & $9 \cdot 7 \%$ & $9.9 \%$ & - \\
$\square \mathrm{SO}_{1.00}$ & $11 \cdot 3 \%$ & $9 \cdot 9 \%$ & $9.0 \%$ & $8.9 \%$ & $8.9 \%$ & - \\
\hline
\end{tabular}

achieved for the same $\mathrm{SO}$ concentration at $N=5 \quad\left(\mathrm{SW}_{\mathrm{P}}\right.$ decreased from $13 \cdot 4 \%$ for $\mathrm{SO}_{0}$ to $9 \cdot 9 \%$ for $\mathrm{SO}_{0 \cdot 75}$ ).

The variations of shrinkage potential $\mathrm{SH}_{\mathrm{P}}$ (obtained by Equation 3) against the number of applied cycles are presented in Figure 3(b). Overall, as evident from the five trend curves in this figure, the variations in shrinkage potential exhibited a trend similar to that observed for the swelling potential; as such, reduction in the shrinkage potential was in favour of increasing both the number of applied cycles (following an exponentially decreasing trend, with only minor added benefits achieved beyond the fourth cycle) and, more importantly, the SO concentration. As a typical case, the natural soil sample resulted in $\mathrm{SH}_{\mathrm{P}}=19 \cdot 3,14 \cdot 2,13 \cdot 9,13 \cdot 4,13 \cdot 1$ and $13 \cdot 0 \%$ at $N=1-6$, respectively. Much like the swelling potential, the tendency for shrinkage potential reduction at any given cycle was also found to be in favour of increasing the SO concentration up to $0 \cdot 75 \% \mathrm{SO}$, beyond which only marginal improvements were noted. At $N=1$, for instance, samples $\mathrm{SO}_{0}, \mathrm{SO}_{0 \cdot 25}$, $\mathrm{SO}_{0.50}, \mathrm{SO}_{0 \cdot 75}$ and $\mathrm{SO}_{1 \cdot 00}$ resulted in $\mathrm{SH}_{\mathrm{P}}=19 \cdot 3,16 \cdot 1,13 \cdot 1$, $12 \cdot 2$ and $12 \cdot 3 \%$, respectively. Unlike the swelling potential, the magnitude of shrinkage improvement at any given SO concentration was not as significantly influenced by the number of applied cycles. As a typical comparative case, sample $\mathrm{SO}_{0.75}$ led to an $18 \%$ improvement in the shrinkage potential at $N=2$ ( $\mathrm{SH}_{\mathrm{P}}$ decreased from $14 \cdot 2 \%$ for $\mathrm{SO}_{0}$ to $11 \cdot 7 \%$ for $\mathrm{SO}_{0.75}$ ), while the same sample achieved a slightly higher improvement of $28 \%$ at $N=5\left(\mathrm{SH}_{\mathrm{P}}\right.$ decreased from $13 \cdot 1 \%$ for $\mathrm{SO}_{0}$ to $9 \cdot 4 \%$ for $\mathrm{SO}_{0 \cdot 75}$ ).

The observed reductions in the swelling and shrinkage potentials, as imposed by alternate wetting and drying, can be

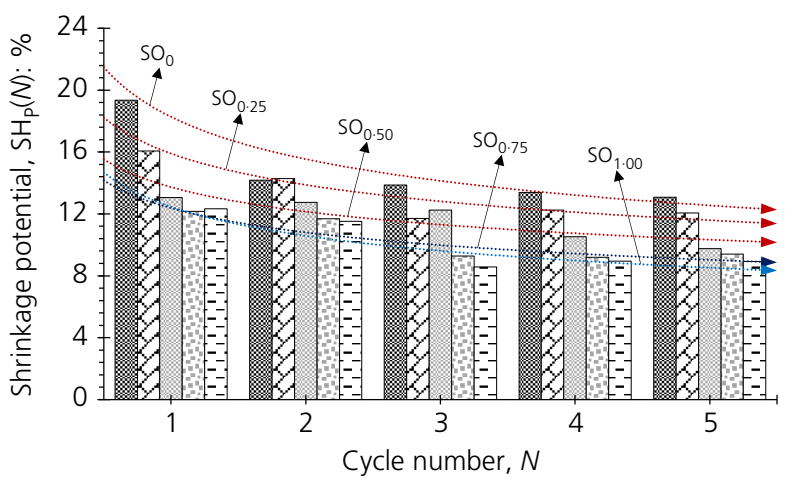

(b)

\begin{tabular}{|l|c|c|c|c|c|c|}
\hline Sample & $N=1$ & $N=2$ & $N=3$ & $N=4$ & $N=5$ & $N=6$ \\
\hline $\mathrm{SO}_{0}$ & $19 \cdot 3 \%$ & $14 \cdot 2 \%$ & $13 \cdot 9 \%$ & $13 \cdot 4 \%$ & $13 \cdot 1 \%$ & $13 \cdot 0 \%$ \\
$\square \mathrm{SO}_{0.25}$ & $16 \cdot 1 \%$ & $14 \cdot 3 \%$ & $11 \cdot 7 \%$ & $12 \cdot 3 \%$ & $12 \cdot 1 \%$ & - \\
$\square \mathrm{SO}_{0.50}$ & $13 \cdot 1 \%$ & $12 \cdot 8 \%$ & $12 \cdot 2 \%$ & $10 \cdot 5 \%$ & $9.8 \%$ & - \\
$\square \mathrm{SO}_{0.75}$ & $12 \cdot 2 \%$ & $11 \cdot 7 \%$ & $9 \cdot 3 \%$ & $9 \cdot 2 \%$ & $9 \cdot 4 \%$ & - \\
$\square \mathrm{SO}_{1.00}$ & $12 \cdot 3 \%$ & $11 \cdot 5 \%$ & $8 \cdot 6 \%$ & $8.9 \%$ & $8.9 \%$ & - \\
\hline
\end{tabular}

Figure 3. Variations of (a) swelling and (b) shrinkage potentials against the number of applied wetting-drying cycles for the natural soil $\left(\mathrm{SO}_{0}\right)$ and $\mathrm{SO}$-treated samples $\left(\mathrm{SO}_{0.25}, \mathrm{SO}_{0.50}, \mathrm{SO}_{0.75}\right.$ and $\left.\mathrm{SO}_{1.00}\right)$ 
attributed to the reconstruction of the soil microstructure on completion of the first and/or second cycle (Al-Homoud et al., 1995; Estabragh et al., 2013, 2015, 2018; Soltani et al., 2018a, 2019a; Subba Rao, 2000; Zhang et al., 2006; Zhao et al., 2019). It can be hypothesised that capillary stresses developed during the first and/or second drying cycle result in the formation and propagation of strong van der Waals bonds between adjacent clay particles in the soil matrix, thereby inducing aggregation of the clay particles. This reconstruction mechanism would likely lead to a notable decrease in the soil's apparent clay content, thereby effectively reducing the soil's specific surface area and hence its water adsorption-retention capacity, in turn producing a reduced tendency for swellshrink volume changes.

Much like polymers, SOs amend the soil fabric through direct interactions with clay particles (Soltani et al., 2019c). As described in Section 1, a typical SO molecule consists of two main components - that is, the negatively charged hydrophilic (or polar) head and the neutral hydrophobic (or non-polar) tail. In the wet or dry condition, the clay particle surface carries an unbalanced negative charge and thus tends to repel the negatively charged SO molecules due to charge repulsion. However, a reasonable attraction may still be achieved through 'exchangeable cations' present in the vicinity of the clay surface, which act as the so-called 'bridges' between the negatively charged hydrophilic heads and the clay surface $(\mathrm{He}$ et al., 2018; Katz et al., 2001; Onyejekwe and Ghataora, 2015; Soltani et al., 2019c; Tingle et al., 2007). The development and propagation of these strong 'cationic bridges' can immobilise the exchangeable cations in the vicinity of the clay surface, thereby reducing the soil's cation-exchange capacity and hence amending the hydrophilic character of the clay particle to hydrophobic or water repellent. Meanwhile, the hydrophobic tails produce a so-called 'oily barrier' around the clay particle, which deprives the clay surface from easy access to ionised water and hence further reduces its water affinity (Mousavi et al., 2014; Mousavi and Karamvand, 2017; Soltani et al., 2017). Theoretically, the greater the number of SO molecules present (i.e. increase in SO concentration), the more water repellent the clay particles become, and thus the lower the soil's swelling and shrinkage potentials. However, the amending mechanisms described above only hold provided that the SO concentration does not exceed its critical micelle concentration (CMC). The CMC refers to the particular SO concentration for which the clay particle surfaces become 'saturated' with SO molecules - in other words, the clay surfaces do not have any vacant sites available to attract additional SO molecules (Park et al., 2006; Sánchez-Martín et al., 2008; Wang et al., 1999). An increase in SO concentration beyond the CMC would likely cause the excess SO molecules to self-associate in the form of aggregates (or micelles); in this case, the excess SO material will act as a lubricant rather than a clay-stabilising agent (Jones et al., 2016; Soltani et al., 2019c). Consequently, in terms of volume changes, an increase in SO concentration beyond the CMC should not produce further reductions in the soil's swelling and shrinkage potentials. As such, this mechanism elucidates the marginal improvements noted in the swelling and shrinkage potentials for SO concentrations greater than $0.75 \%$ (see Figure 3).

\subsection{Cumulative swell-shrink patterns}

The relative swelling and shrinkage potentials - obtained by Equation 3 and outlined in Figure 3 - can be unified in a cumulative manner to perceive the character and extent of the accumulated axial strain, as well as its evolution during the cyclic wetting-drying process, using the following framework (Soltani et al., 2019a, 2019c; Zhao et al., 2019)

$$
\text { 4. } \quad \varepsilon_{\mathrm{ac}}(N)=\left\{\begin{aligned}
& \text { Wetting : } \sum_{N=1}^{K}\left[\operatorname{SW}_{\mathrm{P}}(N)-\right.\left.\mathrm{SH}_{\mathrm{P}}(N-1)\right] ; \\
& N=\{1,2,3, \ldots\} \\
& \text { Drying }: \sum_{N=1}^{K}\left[\operatorname{SW}_{\mathrm{P}}(N)-\right.\left.\mathrm{SH}_{\mathrm{P}}(N)\right] ; \\
& N=\{1,2,3, \ldots\}
\end{aligned}\right.
$$

where $\varepsilon_{\mathrm{ac}}(N)$ is the accumulated axial strain at the end of the $N$ th wetting or drying cycle (in $\%$ ), $\operatorname{SW}_{\mathrm{P}}(N)$ is the swelling potential at the $N$ th wetting cycle (in $\%), \operatorname{SH}_{\mathrm{P}}(N-1)$ and $\mathrm{SH}_{\mathrm{P}}(N)$ are the shrinkage potentials at the $(N-1)$ th and $N$ th drying cycles, respectively (in \%) and $K$ is the total number of imposed wetting-drying cycles.

Figure 4 illustrates the cumulative swell-shrink patterns/ rhythms - expressed in terms of the variations of the accumulated axial strain $\varepsilon_{\mathrm{ac}}$ (obtained by Equation 4) plotted against the number of applied wetting-drying cycles $N$ - for the natural soil and various SO-treated samples. For each sample, the character and extent of the accumulated axial strain was adequately captured through a linear trendline fitted to its respective swell-shrink pattern - that is, $\varepsilon_{\mathrm{ac}}=m N+b$, where $m$ and $b$ are the trendline slope and $y$-axis intercept, respectively. In view of the sign and magnitude of $m$, three different deformational states, namely 'expansive', 'contractive' and 'neutral', can be hypothesised (Soltani et al., 2019c). A positive slope (i.e. $m>0$ ) implies that the overall extent of the incurred swelling strains is greater than that of shrinkage and, as such, the accumulated axial strain is expansive in nature and hence undesirable. In this case, the greater the magnitude of $m$, the higher the tendency for free-surface ground expansions. Besides, $m<0$ indicates that the overall extent of the incurred shrinkage strains is greater than that of swelling, and thus the accumulated axial strain possesses an undesirable, contractive character. In other words, for this case, the greater the absolute value of $m$, the higher the tendency for free-surface ground contractions/settlements. The third case, $m=0$, suggests that the overall extent of the incurred swelling and shrinkage strains are fairly close to each other and, as such, the accumulated 


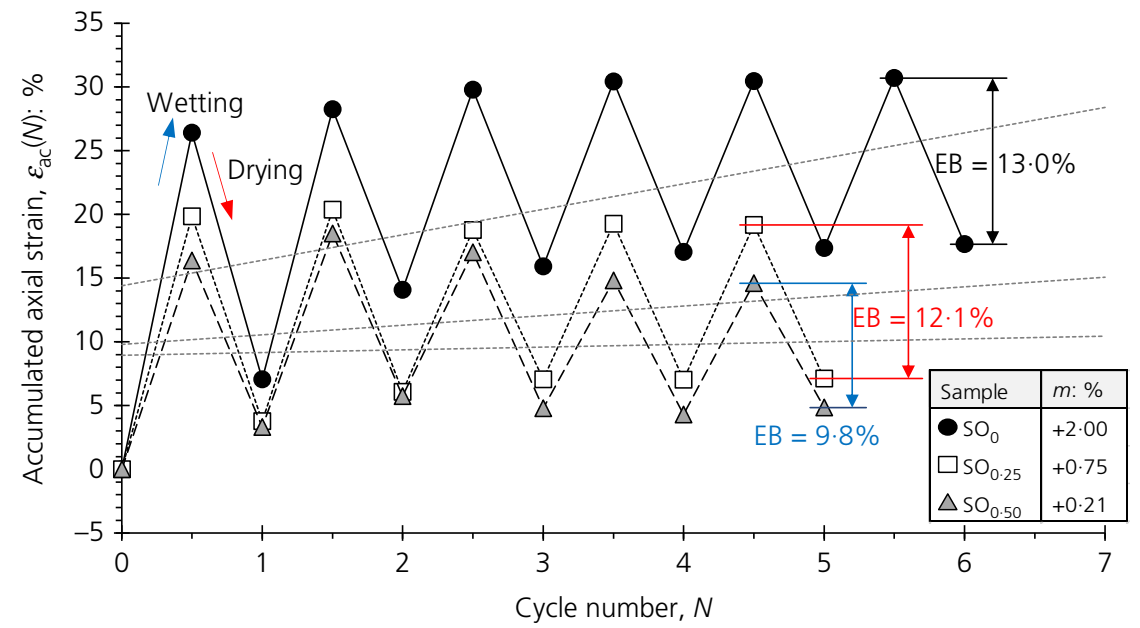

(a)

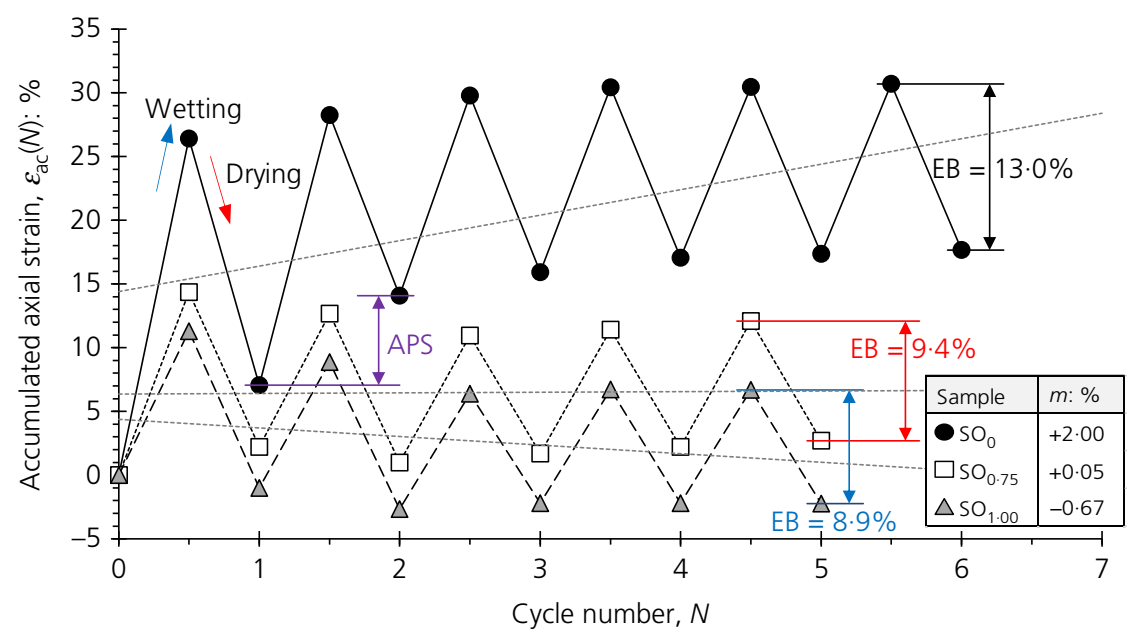

(b)

Figure 4. Cumulative swell-shrink patterns/rhythms of the tested samples: (a) $\mathrm{SO}_{0}, \mathrm{SO}_{0.25}$ and $\mathrm{SO}_{0.50}$; (b) $\mathrm{SO}_{0}, \mathrm{SO}_{0.75}$ and $\mathrm{SO}_{1 \cdot 00}$

axial strain is neutral and hence desirable from the point of view of minimising free-surface ground movements (Soltani et al., 2019a). Referring to Figure 4, as a result of SO treatment, the swell-shrink pattern encountered a progressive downward translation over the $\varepsilon_{\mathrm{ac}}: N$ space - in this regard, the greater the SO concentration, the more pronounced the downward translation. Furthermore, the slope $m$ was found to be inversely proportional to the SO concentration, with a sign change from positive to negative, occurring between $\mathrm{SO}_{0.75}$ and $\mathrm{SO}_{1.00}$ (see Figure 4(b)). Referring to the data tables provided in Figure 4 , the natural soil sample $\left(\mathrm{SO}_{0}\right)$ resulted in $m=+2.00 \%$, indicating an undesirable, expansive condition in response to alternate wetting and drying. As a result of the SO treatment, this value reduced to $+0 \cdot 75,+0 \cdot 21$ and $+0.05 \%$ for samples $\mathrm{SO}_{0.25}, \mathrm{SO}_{0.50}$ and $\mathrm{SO}_{0.75}$, respectively; these results indicate a gradual transition towards a desirable, neutral state, with $0 \cdot 75 \%$ SO exhibiting the highest resistance against the cyclic wetting-drying action. The higher SO concentration of $1 \%$, however, manifested a negative slope of $m=-0 \cdot 67 \%$, thus suggesting an undesirable, contractive behaviour. In view of these trends, it can be concluded that the beneficial effects of SO treatment, even at high concentrations (beyond the $\mathrm{CMC}$ ), are fairly preserved under the influence of alternate wetting and drying.

As is evident from Figure 4, the relative swelling and shrinkage potentials essentially attained a so-called 'elastic equilibrium' state on the completion of four cycles. In other words, the magnitude of the incurred axial plastic strain (APS) - defined as the difference between the swelling and shrinkage potentials for a specific cycle (e.g. see APS dimension for the sample $\mathrm{SO}_{0}$ at $N=2$ in Figure 4(b)) - approached zero on the completion of four cycles, implying that the swelling and shrinkage strains became elastic in nature and hence entirely reversible. Consequently, on achieving elastic equilibrium, the relative swelling and shrinkage potentials evolved into a unique, 
interchangeable value, the equilibrium bandwidth (EB), which signifies the sample's equalised (or ultimate) swell-shrink potential and is defined as the equalised axial strain (\%) (Rao et al., 2008; Subba Rao, 2000; Yazdandoust and Yasrobi, 2010). As outlined in Figure 4, the greater the SO concentration, the smaller the EB and hence the lower the ultimate swell-shrink potential; however, the beneficial effects of the SO treatment progressively reduced beyond $0.5 \% \mathrm{SO}$. That is, the natural soil sample resulted in $\mathrm{EB}=13.0 \%$, whereas the samples treated with $0 \cdot 25,0.5,0.75$ and $1 \%$ SO produced lower values of $12 \cdot 1,9 \cdot 8,9 \cdot 4$ and $8 \cdot 9 \%$, respectively.

\subsection{Equalised void ratio-moisture content swell-shrink paths}

Figure 5 illustrates the variations of void ratio $e$ against moisture content $w$ for the natural soil and various SO-treated

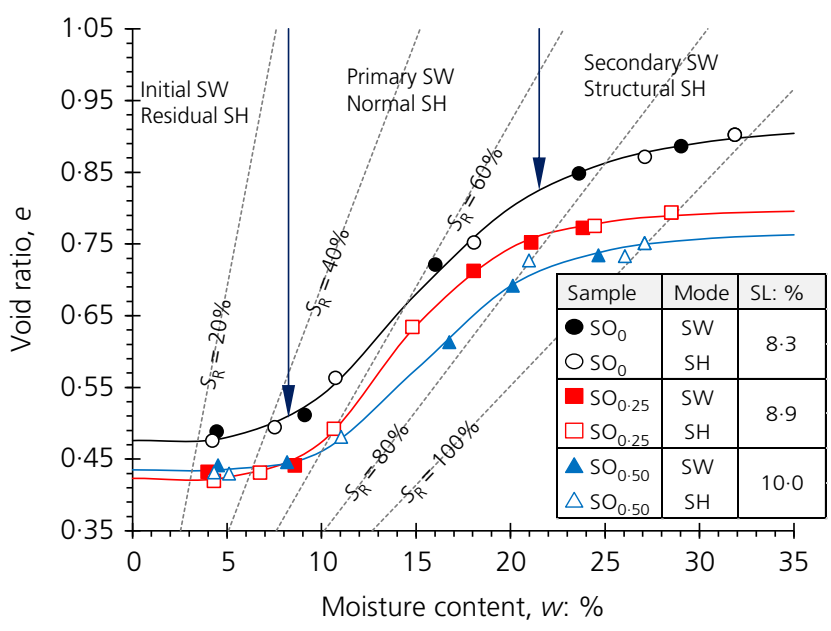

(a)

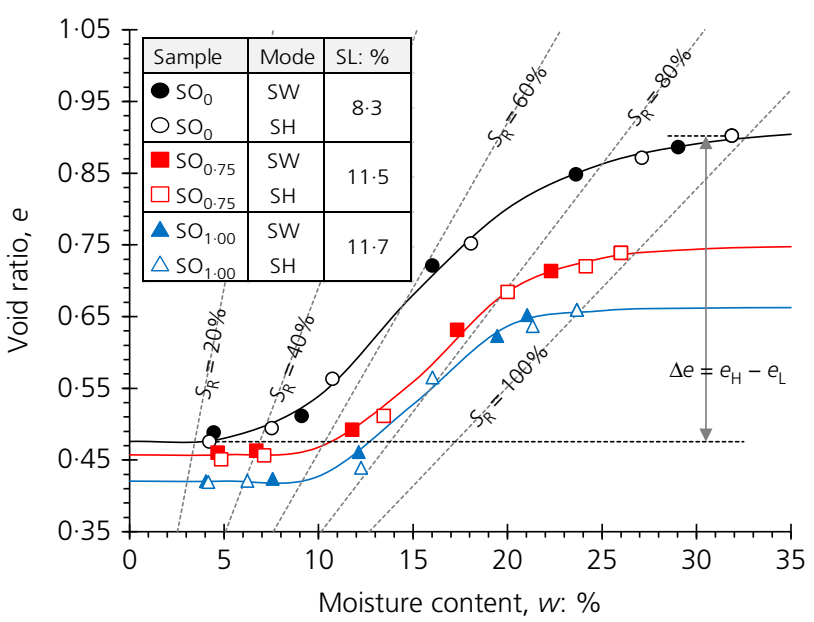

(b)

Figure 5. Equalised void ratio-moisture content swell-shrink paths for the tested samples: (a) $\mathrm{SO}_{0}, \mathrm{SO}_{0.25}$ and $\mathrm{SO}_{0.50}$; (b) $\mathrm{SO}_{0}$, $\mathrm{SO}_{0.75}$ and $\mathrm{SO}_{1.00}$. SW and $\mathrm{SH}$ denote swelling and shrinkage processes, respectively samples at their respective concluding cycle; that is, $N=6$ for $\mathrm{SO}_{0}$ and $N=5$ for $\mathrm{SO}_{0.25}, \mathrm{SO}_{0.50}, \mathrm{SO}_{0 \cdot 75}$ and $\mathrm{SO}_{1 \cdot 00}$. For any given $\mathrm{SO}$ concentration, the $e-w$ data points for swelling and shrinkage were all found to follow the same S-shaped path, thus further corroborating the finding that on achieving elastic equilibrium the swelling and shrinkage processes become completely reversible in character. Consequently, the equalised paths for swelling and shrinkage considering a given SO concentration can be represented by a unique S-shaped curve, which in turn suggests three interchangeable evolvement phases during wetting and drying. For ease of presentation and analysis, the S-shaped swell-shrink characteristic curve was represented by means of the four-parameter logistic function (Equation 5 (Soltani et al., 2019d; Thyagaraj et al., 2017)) with the deduced model parameters for the natural soil and various SO-treated samples presented in Table 4 .

$$
\text { 5. } e(w)=e_{\mathrm{L}}+\frac{e_{\mathrm{H}}-e_{\mathrm{L}}}{1+(\alpha w)^{-\beta}}
$$

where $e(w)$ is the void ratio with respect to moisture content $w, e_{\mathrm{L}}$ is the minimum void ratio - corresponding to commencement of swelling or conclusion of shrinkage, $e_{\mathrm{H}}$ is the maximum void ratio - corresponding to commencement of shrinkage or conclusion of swelling, $\alpha$ is the positive fitting parameter (in $\left.\%^{-1}\right)\left(\alpha^{-1}\right.$ is the moisture content at the curve's inflection point (in \%)) and $\beta$ is the positive fitting parameter, which controls the growth rate (or steepness) of the curve. Note that $e_{\mathrm{L}}$ and $e_{\mathrm{H}}$ can be either fixed or set as independent fitting parameters.

As outlined in Figure 5(a), the swelling process has three distinct stages - namely, 'initial', 'primary' and 'secondary' swelling (Estabragh et al., 2015; Sivapullaiah et al., 1996; Soltani et al., 2019a; Sridharan and Gurtug, 2004; Tripathy et al., 2002). The initial swelling phase, also referred to as inter-void swelling, progresses at the macrostructural level; at this stage, active 'smectite' group minerals undergo expansion within the inter-assemblage pore spaces. Initial swelling continues until such time that the inter-assemblage porespaces are no longer capable of accommodating further clay mineral expansion; as such, this swelling phase leads to minor volume changes, mainly less than $10 \%$ of the total volume increase. Unlike the initial swelling, the primary swelling phase evolves at the microstructural level. In terms of graphical representation, this stage manifests a steep-sloped linear segment over the $e: w$ space, indicating a substantial steady rate of soil expansion with respect to moisture gain; consequently, this swelling phase accounts for up to $80 \%$ of the total volume increase. The secondary swelling phase, which also progresses at the microstructural level, occurs as a result of double-layer repulsion and thus accounts for small time-dependent increases in soil volume. Unlike the primary swelling, both the initial and secondary swelling phases are graphically represented by mild-sloped curvilinear segments (see Figure 5(a)). Much like 
swelling, the evolution of shrinkage for a fully swollen sample also has three distinct stages - namely, 'structural', 'normal' (or 'primary') and 'residual' shrinkage (Cornelis et al., 2006; Estabragh et al., 2015; Haines, 1923; Soltani et al., 2019d; Thyagaraj et al., 2017; Tripathy et al., 2002). The structural shrinkage phase evolves at the macrostructural level and involves drainage of moisture from the larger inter-assemblage pore spaces, thereby producing relatively minor volume reductions. As outlined in Figure 5(a), on achieving swellshrink equilibrium, structural shrinkage becomes interchangeable with secondary swelling. Much like primary swelling, the normal (or primary) shrinkage phase is graphically represented by a steep-sloped linear segment, thus signifying a substantial steady rate of soil contraction with respect to moisture loss. This portion of the shrinkage curve, regardless of attaining swell-shrink equilibrium, is essentially parallel to the $S_{\mathrm{R}}=100 \%$ saturation line. As such, any decrease in moisture volume leads to an equal decrease in the bulk soil volume. The normal shrinkage phase continues until such time that the soil particles come into close contact and the contained moisture is just sufficient to fill the intra-assemblage pore spaces; the moisture content at this juncture is defined as the 'shrinkage limit (SL)'. The residual shrinkage phase, which becomes interchangeable with initial swelling, marks the entrance of air into the intra-assemblage pore spaces, thereby promoting air-filled porosity, along with a dense particle configuration. At this stage, the volume of lost moisture exceeds the encountered decrease in the bulk soil volume.

With an increase in SO concentration, the swell-shrink characteristic curve underwent a progressive vertical contraction over the $e: w$ space (see Figure 5), thus signifying a reduced tendency for swell-shrink volume changes. Moreover, with an increase in SO concentration, the primary swelling (or normal shrinkage) segment of the curve progressively shifted towards the $S_{\mathrm{R}}=100 \%$ saturation line, thus indicating a gradual transition towards a saturated character/condition. As demonstrated for the natural soil sample $\left(\mathrm{SO}_{0}\right)$ in Figure $5(\mathrm{~b})$, the swell-shrink characteristic curve can be employed to quantify the sample's equalised volumetric strain (hereafter referred to as the swell-shrink capacity (SSC)) by means of basic volumemass relations. In other words, the $\mathrm{SSC}$, defined as the equalised volumetric strain during wetting or drying (in \%), is given by (Dash and Hussain, 2015; Soltani et al., 2019a; Thyagaraj et al., 2017)

6. $\operatorname{SSC}(\%)=\frac{e_{\mathrm{H}}-e_{\mathrm{L}}}{1+e_{\mathrm{H}}} \times 100$

where $e_{\mathrm{L}}$ and $e_{\mathrm{H}}$ are the minimum and maximum measured void ratios, respectively, on achieving swell-shrink equilibrium (values are given in Table 4).

As expected, the SSC demonstrated a trend similar to that observed for the EB outlined in Figure 4. The natural soil sample resulted in $\mathrm{SSC}=22.4 \% \quad(\mathrm{~EB}=13.0 \%)$, whereas the samples treated with $0.25,0.5,0.75$ and $1 \%$ SO produced lower values of $\mathrm{SSC}=20 \cdot 9,18 \cdot 4,16 \cdot 6$ and $14 \cdot 5 \%(\mathrm{~EB}=12 \cdot 1$, $9 \cdot 8,9 \cdot 4$ and $8.9 \%$ ), respectively. On the basis of these results, the average SSC/EB ratio for the samples under investigation can be calculated as $1 \cdot 74$. Making use of basic strain-geometry relations, the equalised diametrical strain (EDS, in \%) can be calculated as a function of the equalised volumetric (SSC) and axial (EB) strains

7. $\operatorname{EDS}(\%)=\left(\sqrt{\frac{1+\mathrm{SSC}}{1+\mathrm{EB}}}-1\right) \times 100$

The computed EDS values demonstrated a trend similar to that observed for the $\mathrm{EB}$ (and hence the SSC); samples $\mathrm{SO}_{0}$, $\mathrm{SO}_{0.25}, \mathrm{SO}_{0 \cdot 50}, \mathrm{SO}_{0.75}$ and $\mathrm{SO}_{1 \cdot 00}$ resulted in $\mathrm{EDS}=4 \cdot 1,3 \cdot 9$, $3 \cdot 8,3 \cdot 2$ and $2 \cdot 5 \%$, respectively. In terms of magnitude, however, the EB values were consistently greater than their EDS counterparts. In this regard, the average EB/EDS ratio can be calculated as 3.06 , thus indicating anisotropic behaviour under the imposed oedometer testing conditions. It should be noted that these observations are in agreement with those previously reported in the literature (Estabragh et al., 2015, 2018; Tripathy et al., 2002).

Making use of Equation 5, along with basic geometrical laws, the equalised SL can be objectively quantified by means of

Table 4. Summary of the regression analyses outputs with respect to Equation 5

\begin{tabular}{|c|c|c|c|c|c|c|c|c|}
\hline Sample & $e_{L}^{a}$ & $e_{L}^{b}$ & $e_{H}^{a}$ & $e_{H}^{b}$ & $\alpha: \%^{-1}$ & $\alpha^{-1}: \%^{c}$ & $\beta$ & $R^{2}$ \\
\hline $\mathrm{SO}_{0}$ & 0.467 & 0.476 & 0.902 & 0.921 & $6.40 \times 10^{-2}$ & $15 \cdot 62$ & 4.03 & 0.978 \\
\hline $\mathrm{SO}_{0.25}$ & 0.419 & 0.423 & 0.794 & 0.799 & $7.01 \times 10^{-2}$ & 14.26 & $5 \cdot 24$ & 0.979 \\
\hline $\mathrm{SO}_{0.50}$ & 0.430 & 0.435 & 0.751 & 0.768 & $6.28 \times 10^{-2}$ & $15 \cdot 93$ & $5 \cdot 32$ & 0.977 \\
\hline $\mathrm{SO}_{0.75}$ & 0.451 & 0.457 & 0.739 & 0.750 & $6.05 \times 10^{-2}$ & $16 \cdot 52$ & $6 \cdot 54$ & 0.978 \\
\hline $\mathrm{SO}_{1.00}$ & 0.419 & 0.421 & 0.659 & 0.663 & $6.48 \times 10^{-2}$ & $15 \cdot 44$ & $8 \cdot 15$ & 0.976 \\
\hline
\end{tabular}

${ }^{\mathrm{a}}$ Measured

${ }^{b}$ Fitted

'Moisture content at the curve's inflection point 
Equations 8a and 8b (Soltani et al., 2018b, 2019e)

8a. $\quad \operatorname{SL}(\%)=\frac{\left[e\left(w_{\mathrm{L}}\right)-e\left(\alpha^{-1}\right)\right]+\left[\alpha^{-1} f_{w}^{\prime}\left(\alpha^{-1}\right)-w_{\mathrm{L}} f_{w}^{\prime}\left(w_{\mathrm{L}}\right)\right]}{f_{w}^{\prime}\left(\alpha^{-1}\right)-f_{w}^{\prime}\left(w_{\mathrm{L}}\right)}$

8b. $\quad f_{w}^{\prime}(w)=\frac{\left(e_{\mathrm{H}}-e_{\mathrm{L}}\right) \beta \alpha^{-\beta} w^{-(\beta+1)}}{\left[1+(\alpha w)^{-\beta}\right]^{2}}$

where $e\left(w_{\mathrm{L}}\right)$ is the void ratio at the minimum measured moisture content (which can be obtained by substituting $w=w_{\mathrm{L}}$ into Equation 5), $e\left(\alpha^{-1}\right)$ is the void ratio at the curve's inflection point (which can be obtained by substituting $w=\alpha^{-1}$ into Equation 5), $f_{w}^{\prime}(w)$ is the first derivative of Equation 5 with respect to $w$ and $f_{w}^{\prime}\left(\alpha^{-1}\right)$ is the first derivative of Equation 5 with respect to $w$ at the curve's inflection point, which can be obtained by substituting $w=\alpha^{-1}$ into Equation 8 b.

Referring to the data tables in Figure 5, the SL exhibited a notable increase with an increase in SO concentration. The natural soil resulted in $\mathrm{SL}=8 \cdot 3 \%$, whereas the samples treated with $0 \cdot 25,0 \cdot 5,0.75$ and $1 \%$ SO produced higher values of 8.9 , $10 \cdot 0,11 \cdot 5$ and $11 \cdot 7 \%$, respectively. The SL and LL can be employed to predict and hence perceive the development of the soil fabric (Dash and Hussain, 2015; Muguda and Nagaraj, 2019; Sivapullaiah et al., 2000; Thyagaraj and Zodinsanga, 2014). An increase in the SL, together with a decrease in the LL, as was the case for the SO-treated blends (see Table 3 and Figure 5), indicates that an aggregated fabric dominates the soil matrix. In this regard, the maximum tendency for particle aggregation seemed to be achieved at $0.75 \% \mathrm{SO}$, which, as discussed in Section 4.1, marks the SO's CMC. Beyond the CMC, the SO's lubricant features seem to dominate its particle aggregation properties; this transition elucidates the relatively minor variations encountered in the SL and LL for SO concentrations greater than $0 \cdot 75 \%$.

It is well accepted that the SL is inversely proportional to the packing capacity of the soil particles during drying; as such, its evolution is expected to be governed by the soil's apparent grain-size distribution. Theoretically, the more uniform the soil's gradation, the lower its particle packing capacity and hence the higher its developed SL (Sridharan and Prakash, 1998, 2000). The addition of SO to a host soil would likely produce a more uniform gradation by way of inducing aggregation of the clay particles - in other words, it can be hypothesised that the clay particles undergo a general so-called 'gradational transition', thereby increasing the relative proportion of silt- and/or sand-sized particles (agglomerations) present. This gradational transition offsets the original wellgraded distribution of the host soil and thus gives rise to higher SLs.

\section{Concluding remarks}

The effects of a SO stabiliser on the volume change potential of an expansive soil were investigated through cyclic wettingdrying tests. In addition, basic principles of chemistry, together with the soil consistency framework, were employed to predict and hence perceive the evolution of the soil fabric in response to both SO treatment and cyclic wetting-drying. Based on the experimental results and their interpretation, the following conclusions were drawn.

For any given SO concentration, the greater the number of wetting-drying cycles applied, the lower the swelling and shrinkage potentials, following an exponentially decreasing trend up to the fourth cycle. Beyond the fourth cycle, the swelling and shrinkage strains attained a so-called 'elastic equilibrium' state. Accordingly, it is hypothesised that alternate wetting and drying led to reconstruction of the soil microstructure by way of inducing aggregation of the clay particles.

- At any given cycle, the tendency for swell-shrink reduction was found to be in favour of the SO concentration up to $0 \cdot 75 \% \mathrm{SO}$. It is speculated that an increase in SO concentration beyond this level caused the excess SO molecules to self-associate in the form of aggregates (or micelles). In this case, the excess SO material would likely act as a lubricant rather than a clay-stabilising agent and, as such, would not produce further reductions in the swelling and shrinkage potentials. Moreover, with an increase in SO concentration, the accumulated axial strain progressively transitioned towards a desirable, neutral state; in this regard, $0 \cdot 75 \%$ SO exhibited the highest resistance against cyclic wetting-drying and hence was deemed as the optimum concentration. Additional strength-based tests, such as unconfined compression tests, should be performed and cross-checked with the results obtained in this study to further understand the effects of SO lubrication and to corroborate the optimum SO concentration.

- For any given SO concentration, the equalised void ratio-moisture content data points for wetting and drying followed the same S-shaped path, thus further corroborating that the swelling and shrinkage processes, on achieving elastic equilibrium, become reversible in character. Accordingly, the S-shaped swell-shrink characteristic curve suggested three interchangeable evolvement phases during wetting and drying - namely, initial swelling/residual shrinkage, primary swelling/normal shrinkage and secondary swelling/structural shrinkage. Furthermore, the equalised volumetric and diametrical strains, computed from the S-shaped curves, were found to follow a trend similar to that observed for the equalised axial strains.

- Finally, the SL and LL were employed to predict and hence perceive the development of the soil fabric. 
The greater the SO concentration, the higher the equalised SL and the lower the LL up to $0 \cdot 75 \%$ SO, beyond which the effects of increasing SO concentration were found to be marginal. Accordingly, the maximum tendency for particle aggregation, as achieved through clay-SO interactions, was obtained at $0 \cdot 75 \% \mathrm{SO}$ for the $\mathrm{CH}$ soil investigated.

Although the SO treatment demonstrated great promise in reducing the swell-shrink potential of the expansive soil examined under controlled laboratory conditions, additional research by way of a comprehensive field trial equipped with conventional stress-strain instrumentation is still required to translate/upscale the experimental outcomes to practice. In this context, suitable field applications may include stabilisation of low-volume unpaved roads and expansive soil subgrades. Furthermore, a comparison between cementitious/calciumbased binders and the SO agent should be carried out to better understand the benefits of SO treatment in the context of ground improvement projects.

\section{REFERENCES}

Akbulut S, Kurt ZN and Arasan S (2012) Surfactant modified clays' consistency limits and contact angles. Earth Sciences Research Journal 16(2): 95-101.

Al-Homoud AS, Basma AA, Malkawi AlH and Al-Bashabsheh MA (1995) Cyclic swelling behavior of clays. Journal of Geotechnical Engineering 121(7): 562-565, https://doi.org/10.1061/(asce)07339410(1995)121:7(562).

Al-Rawas AA, Hago AW and Al-Sarmi H (2005) Effect of lime, cement and Sarooj (artificial pozzolan) on the swelling potential of an expansive soil from Oman. Building and Environment 40(5): 681-687, https://doi.org/10.1016/j.buildenv.2004.08.028.

ASTM (2004) D 427-04: Test method for shrinkage factors of soils by the mercury method. ASTM International, West Conshohocken, PA, USA, https://doi.org/10.1520/d0427-04.

ASTM (2007) D 422-63(2007)e2: Standard test method for particle-size analysis of soils. ASTM International, West Conshohocken, PA, USA, https://doi.org/10.1520/d0422-63r07e02.

ASTM (2012) D 698-12e2: Standard test methods for laboratory compaction characteristics of soil using standard effort $\left(12,400 \mathrm{ft}-\mathrm{lbf} / \mathrm{ft}^{3}\left(600 \mathrm{kN}-\mathrm{m} / \mathrm{m}^{3}\right)\right)$. ASTM International, West Conshohocken, PA, USA, https://doi.org/10.1520/ d0698-12e02.

ASTM (2014a) D 854-14: Standard test methods for specific gravity of soil solids by water pycnometer. ASTM International, West Conshohocken, PA, USA, https://doi.org/10.1520/d0854-14.

ASTM (2014b) D 4546-14e1: Standard test methods for onedimensional swell or collapse of soils. ASTM International, West Conshohocken, PA, USA, https://doi.org/10.1520/d4546-14e01.

ASTM (2017a) D 4318-17el: Standard test methods for liquid limit, plastic limit, and plasticity index of soils. ASTM International, West Conshohocken, PA, USA, https://doi.org/10.1520/ d4318-17e01.

ASTM (2017b) D 2487-17: Standard practice for classification of soils for engineering purposes (unified soil classification system). ASTM International, West Conshohocken, PA, USA, https://doi.org/10.1520/d2487-17.

ASTM (2019) D 2216-19: Standard test methods for laboratory determination of water (moisture) content of soil and rock by mass. ASTM International, West Conshohocken, PA, USA https://doi.org/10.1520/d2216-19.

Berney ES, Peters JF, Newman JK and Smith DM (2003) Effect of surfactant on dry-side compaction of silty sand. Transportation Research Record 1819: 57-62, https://doi.org/10.3141/1819b-08.

BIS (Bureau of Indian Standards) (1970) IS 1948-70: Indian standard classification and identification of soils for general engineering purposes. BIS, New Delhi, India.

Cornelis WM, Corluy J, Medina $\mathrm{H}$ et al. (2006) Measuring and modelling the soil shrinkage characteristic curve. Geoderma 137(1-2): 179-191, https://doi.org/10.1016/j.geoderma.2006.08.022.

Dash SK and Hussain M (2015) Influence of lime on shrinkage behavior of soils. Journal of Materials in Civil Engineering 27(12): 04015041: 1-9, https://doi.org/10.1061/(asce)mt.1943-5533. 0001301 .

Estabragh AR, Pereshkafti MRS, Parsaei B and Javadi AA (2013) Stabilised expansive soil behaviour during wetting and drying. International Journal of Pavement Engineering 14(4): 418-427, https://doi.org/ 10.1080/10298436.2012.746688.

Estabragh AR, Rafatjo $\mathrm{H}$ and Javadi AA (2014) Treatment of an expansive soil by mechanical and chemical techniques. Geosynthetics International 21(3): 233-243, https://doi.org/ 10.1680/gein.14.00011.

Estabragh AR, Parsaei B and Javadi AA (2015) Laboratory investigation of the effect of cyclic wetting and drying on the behaviour of an expansive soil. Soils and Foundations 55(2): 304-314, https://doi.org/10.1016/j.sandf.2015.02.007.

Estabragh AR, Soltani A and Javadi AA (2018) Effect of pore water chemistry on the behaviour of a kaolin-bentonite mixture during drying and wetting cycles. European Journal of Environmental and Civil Engineering (in press), https://doi.org/ 10.1080/19648189.2018.1428691

Garzón E, Cano M, O’Kelly BC and Sánchez-Soto PJ (2015) Phyllite clay-cement composites having improved engineering properties and material applications. Applied Clay Science 114: 229-233, https://doi.org/10.1016/j.clay.2015.06.006.

Garzón E, Cano M, O’Kelly BC and Sánchez-Soto PJ (2016) Effect of lime on stabilization of phyllite clays. Applied Clay Science 123: 329-334, https://doi.org/10.1016/j.clay.2016.01.042.

Greening PAK and Page-Green P (2003) Evaluation of Sulphonated Petroleum Products as Soil Stabilisers and Compaction Aids. Transport Research Laboratory, Crowthorne, UK, Project Report PR/INT/267/03.

gTKP (global Transport Knowledge Practice) (2006) The Sulfonated Petroleum Products Toolkit 2 for Engineers. gTKP, Wokingham, UK. See https://www.gtkp.com/communications-list (accessed 01/06/2013).

Haines WB (1923) The volume-changes associated with variations of water content in soil. Journal of Agricultural Science 13(3): 296-310, https://doi.org/10.1017/s0021859600003580.

He S, Yu X, Banerjee A and Puppala AJ (2018) Expansive soil treatment with liquid ionic soil stabilizer. Transportation Research Record 2672: 185-194, https://doi.org/10.1177/0361198118792996.

Jha AK and Sivapullaiah PV (2016) Gypsum-induced volume change behavior of stabilized expansive soil with fly ash-lime. Geotechnical Testing Journal 39(3): 391-406, https://doi.org/ $10.1520 /$ gtj20150017.

Jones LD and Jefferson I (2012) Expansive soils. In ICE Manual of Geotechnical Engineering: Volume I (Burland J, Chapman T, Brown $\mathrm{M}$ and Skinner H (eds)). ICE Publishing, London, UK, pp. 413-441, https://doi.org/10.1680/moge.57074.0413.

Jones N, Lourenço SDN and Paul A (2016) Testing surfactants as additives for clay improvement: compaction and suction effects. E3S Web of Conferences 9: 13006, https://doi.org/10.1051/ e3sconf/20160913006. 
Katz L, Rauch A, Liljestrand H et al. (2001) Mechanisms of soil stabilization with liquid ionic stabilizer. Transportation Research Record 1757: 50-57, https://doi.org/10.3141/1757-06.

Liu QB, Xiang W, Zhang WF and Cui DS (2009) Experimental study of ionic soil stabilizer-improves expansive soil. Rock and Soil Mechanics 30(8): 2286-2290.

March J (1992) Advanced Organic Chemistry: Reactions, Mechanisms, and Structure, 4th edn. Wiley, New York, NY, USA.

Mousavi SE and Karamvand A (2017) Assessment of strength development in stabilized soil with CBR PLUS and silica sand. Journal of Traffic and Transportation Engineering (English Edition) 4(4): 412-421, https://doi.org/10.1016/j.jtte.2017.02.002.

Mousavi F, Abdi E and Rahimi H (2014) Effect of polymer stabilizer on swelling potential and CBR of forest road material. KSCE Journal of Civil Engineering 18(7): 2064-2071, https://doi.org/ 10.1007/s12205-014-0137-7.

Muguda S and Nagaraj HB (2019) Effect of enzymes on plasticity and strength characteristics of an earthen construction material. International Journal of Geo-Engineering 10(1), 2: 1-14, https://doi.org/10.1186/s40703-019-0098-2.

Nalbantoglu Z and Tuncer ER (2001) Compressibility and hydraulic conductivity of a chemically treated expansive clay. Canadian Geotechnical Journal 38(1): 154-160, https://doi.org/10.1139/ t00-076.

Nelson JD and Miller DJ (1992) Expansive Soils: Problems and Practice in Foundation and Pavement Engineering, 1st edn. Wiley, New York, NY, USA.

Onyejekwe S and Ghataora GS (2015) Soil stabilization using proprietary liquid chemical stabilizers: sulphonated oil and a polymer. Bulletin of Engineering Geology and the Environment 74(2): 651-665, https://doi.org/10.1007/s10064-014-0667-8.

Park J, Vipulanandan C, Kim JW and Oh MH (2006) Effects of surfactants and electrolyte solutions on the properties of soil. Environmental Geology 49(7): 977-989, https://doi.org/10.1007/ s00254-005-0136-6.

Petry TM and Das B (2001) Evaluation of chemical modifiers and stabilizers for chemically active soils - clays. Transportation Research Record 1757: 43-49, https://doi.org/10.3141/1757-05.

Phanikumar BR and Nagaraju TV (2018) Engineering behaviour of expansive clays blended with cement and GGBS. Proceedings of the Institution of Civil Engineers - Ground Improvement 171(3): 167-173, https://doi.org/10.1680/jgrim.17.00054.

Rao MR, Rao AS and Babu DR (2008) Efficacy of lime-stabilised fly ash in expansive soils. Proceedings of the Institution of Civil Engineers - Ground Improvement 161(1): 23-29, https://doi.org/ 10.1680/grim.2008.161.1.23

Sánchez-Martín MJ, Dorado MC, del Hoyo C and Rodríguez-Cruz MS (2008) Influence of clay mineral structure and surfactant nature on the adsorption capacity of surfactants by clays. Journal of Hazardous Materials 150(1): 115-123, https://doi.org/10.1016/ j.jhazmat.2007.04.093.

Scholen DE (1992) Non-Standard Stabilizers. Federal Highway Administration, Washington, DC, USA, Project Report FHWAFLP-92-011.

Scholen DE (1995) Stabilizer mechanisms in nonstandard stabilizers. In Proceedings of the 6th International Conference on Low-Volume Roads. Transportation Research Board Executive Committee, Washington, DC, USA, pp. 252-260.

Sharma AK and Sivapullaiah PV (2016) Ground granulated blast furnace slag amended fly ash as an expansive soil stabilizer. Soils and Foundations 56(2): 205-212, https://doi.org/10.1016/ j.sandf.2016.02.004.

Sivapullaiah PV, Sridharan A and Stalin VK (1996) Swelling behaviour of soil-bentonite mixtures. Canadian Geotechnical Journal 33(5): 808-814, https://doi.org/10.1139/t96-106-326.
Sivapullaiah PV, Sridharan A and Raju Bhaskar KV (2000) Role of amount and type of clay in the lime stabilization of soils. Proceedings of the Institution of Civil Engineers - Ground Improvement 4(1): 37-45, https://doi.org/10.1680/grim.2000.4.1.37.

Soltani A, Taheri A, Khatibi M and Estabragh AR (2017) Swelling potential of a stabilized expansive soil: a comparative experimental study. Geotechnical and Geological Engineering 35(4): 1717-1744, https://doi.org/10.1007/s10706-017-0204-1.

Soltani A, Deng A, Taheri A and Mirzababaei M (2018a) Rubber powder-polymer combined stabilization of south Australian expansive soils. Geosynthetics International 25(3): 304-321, https://doi.org/10.1680/jgein.18.00009.

Soltani A, Deng A, Taheri A, Sridharan A and Estabragh AR (2018b) A framework for interpretation of the compressibility behavior of soils. Geotechnical Testing Journal 41(1): 1-16, https://doi.org/ $10.1520 /$ gtj20170088.

Soltani A, Deng A, Taheri A, Mirzababaei M and Vanapalli SK (2019a) Swell-shrink behavior of rubberized expansive clays during alternate wetting and drying. Minerals 9(4): 224: 1-18, https://doi.org/10.3390/min9040224.

Soltani A, Taheri A, Deng A and Nikraz H (2019b) Tyre rubber and expansive soils: two hazards, one solution. Proceedings of the Institution of Civil Engineers - Construction Materials 1-17 (in press), https://doi.org/10.1680/jcoma.18.00075.

Soltani A, Deng A, Taheri A and Mirzababaei M (2019c) A sulphonated oil for stabilisation of expansive soils. International Journal of Pavement Engineering 20(11): 1285-1298, https://doi.org/10.1080/ 10298436.2017.1408270.

Soltani A, Deng A, Taheri A and Sridharan A (2019d) Swell-shrinkconsolidation behavior of rubber-reinforced expansive soils. Geotechnical Testing Journal 42(3): 761-788, https://doi.org/ $10.1520 / g t j 20170313$.

Soltani A, Azimi M, Deng A and Taheri A (2019e) A simplified method for determination of the soil-water characteristic curve variables. International Journal of Geotechnical Engineering 13(4): 316-325, https://doi.org/10.1080/19386362.2017.1344450.

Sridharan A and Gurtug Y (2004) Swelling behaviour of compacted fine-grained soils. Engineering Geology 72(1-2): 9-18, https://doi.org/10.1016/s0013-7952(03)00161-3.

Sridharan A and Prakash K (1998) Mechanism controlling the shrinkage limit of soils. Geotechnical Testing Journal 21(3): 240-250, https://doi.org/10.1520/gtj10897j.

Sridharan A and Prakash K (2000) Shrinkage limit of soil mixtures. Geotechnical Testing Journal 23(1): 3-8, https://doi.org/ $10.1520 / \mathrm{gtj} 11118 \mathrm{j}$.

Subba Rao KS (2000) Swell-shrink behaviour of expansive soils - geotechnical challenges. Indian Geotechnical Journal 30(1): $1-68$.

Thyagaraj T and Zodinsanga S (2014) Swell-shrink behaviour of lime precipitation treated soil. Proceedings of the Institution of Civil Engineers - Ground Improvement 167(4): 260-273, https://doi.org/ 10.1680/grim.12.00028.

Thyagaraj T, Thomas SR and Das AP (2017) Physico-chemical effects on shrinkage behavior of compacted expansive clay. International Journal of Geomechanics 17(2): 06016013: 1-11, https://doi.org/ 10.1061/(asce)gm.1943-5622.0000698.

Tingle JS, Newman JK, Larson SL, Weiss CA and Rushing JF (2007) Stabilization mechanisms of nontraditional additives. Transportation Research Record 1989: 59-67, https:/doi.org/ 10.3141/1989-49.

Tripathy S and Subba Rao KS (2009) Cyclic swell-shrink behaviour of a compacted expansive soil. Geotechnical and Geological Engineering 27(1): 89-103, https://doi.org/10.1007/s10706-008-9214-3.

Tripathy S, Subba Rao KS and Fredlund DG (2002) Water content-void ratio swell-shrink paths of compacted expansive soils. 
Canadian Geotechnical Journal 39(4): 938-959, https://doi.org/ 10.1139/t02-022.

Wang J, Han B, Dai M et al. (1999) Effects of chain length and structure of cationic surfactants on the adsorption onto $\mathrm{Na}-$ kaolinite. Journal of Colloid and Interface Science 213(2): 596-601, https://doi.org/10.1006/jcis.1999.6147.

Williamson S and Cortes DD (2014) Dimensional analysis of soil-cement mixture performance. Géotechnique Letters 4(1): 33-38, https://doi.org/10.1680/geolett.13.00082.

Winterkorn HF and Pamukcu S (1991) Soil stabilization and grouting. In Foundation Engineering Handbook (Fang HY (ed.)). Springer, Boston, MA, USA, pp. 317-378, https://doi.org/10.1007/ 978-1-4615-3928-5_9.

Xiang W, Cui D, Liu Q, Lu X and Cao L (2010) Theory and practice of ionic soil stabilizer reinforcing special clay. Journal of Earth Science 21(6): 882-887, https://doi.org/10.1007/s12583-010-0141-x.
Yazdandoust F and Yasrobi SS (2010) Effect of cyclic wetting and drying on swelling behavior of polymer-stabilized expansive clays. Applied Clay Science 50(4): 461-468, https://doi.org/10.1016/ j.clay.2010.09.006.

Zhang $\mathrm{R}$, Yang $\mathrm{H}$ and Zheng J (2006) The effect of vertical pressure on the deformation and strength of expansive soil during cyclic wetting and drying. In Proceedings of the 4th International Conference on Unsaturated Soils (Miller GA, Zapata CE, Houston SL and Fredlund DG (eds)). ASCE, Reston, VA, USA, pp. 894-905, https://doi.org/10.1061/ 40802(189)71.

Zhao NF, Ye WM, Chen YG, Chen B and Cui YJ (2019) Investigation on swelling-shrinkage behavior of unsaturated compacted GMZ bentonite on wetting-drying cycles. Bulletin of Engineering Geology and the Environment 78(1): 617-627, https://doi.org/ 10.1007/s10064-017-1095-3.

\section{How can you contribute?}

To discuss this paper, please email up to 500 words to the editor at journals@ice.org.uk. Your contribution will be forwarded to the author(s) for a reply and, if considered appropriate by the editorial board, it will be published as discussion in a future issue of the journal.

Proceedings journals rely entirely on contributions from the civil engineering profession (and allied disciplines). Information about how to submit your paper online is available at www.icevirtuallibrary.com/page/authors, where you will also find detailed author guidelines. 